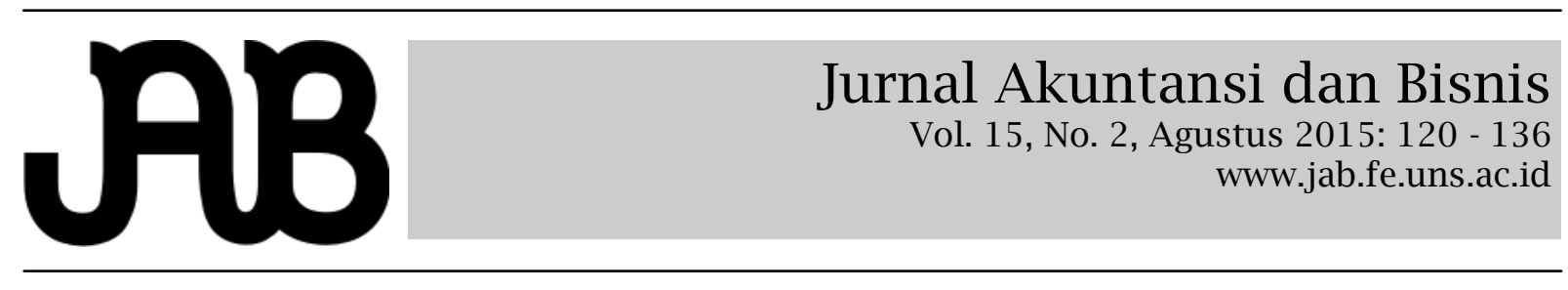

\title{
PENGARUH EARNINGS MANAGEMENT TERHADAP CORPORATE ENVI- RONMENTAL RESPONSIBILITY DISCLOSURE DENGAN MEKANISME COR- PORATE GOVERNANCE SEBAGAI VARIABEL PEMODERASI (Studi Empiris Perusahaan Manufaktur yang Terdaftar di BEI tahun 2008-2011)
}

\author{
MARLINA EKA SETYORINI \\ SRI SURANTA (srisuranta1@gmail.com)
}

Fakultas Ekonomi dan Bisnis Universitas Sebelas Maret

\begin{abstract}
A B S T R A C T
This study examines the effect of earnings management on corporate environmental responsibility disclosure with corporate governance mechanisms as a moderating variable in the relationship. Corporate governance mechanisms in this study is proxied by four variables: the proportion of independent commissioner, the number of audit committee members, institutional ownership, and managerial ownership. This study is also to uses profitability, leverage, and firm size as a control variables. Earnings Management in this research is measured using Eckel Index (1981). This study uses a sample of manufacturing companies listed on the Indonesia Stock Exchange in 2008-2011. Data were obtained from the annual report, the company's official website, the financial statements, and sustainability reports of manufacturing companies listed on the Indonesia Stock Exchange. Samples were obtained using a purposive sampling method. Hypothesis testing method used is multiple regression analysis with dummy variables. There is a 48 company per years that meet the criteria of the study sample. The results of this study indicate that the independent commissioner, audit committee and managerial ownership has no significant effect in moderating the effect of earnings management on corporate environmental responsibility disclosure. Meanwhile, influential institutional ownership significantly. Two of the three control variables used in this study, namely profitability and leverage doesn't have a significant influence on the effect of earnings management on corporate environmental responsibility disclosure, while the influence of institutional ownership has a significant influence on the effects of earnings management to corporate environmental responsibility disclosure.

Keywords: Earnings Management, Corporate Environmental Responsibility Disclosure, Corporate Governance.
\end{abstract}

Penelitian ini menguji pengaruh manajemen laba pada pengungkapan tanggung jawab lingkungan perusahaan dengan mekanisme tata kelola perusahaan sebagai variabel moderasi dalam hubungan. Mekanisme tata kelola perusahaan dalam penelitian ini diproksikan dengan empat variabel: proporsi komisaris independen, jumlah anggota komite audit, kepemilikan institusional, dan kepemilikan manajerial. Penelitian ini juga untuk penggunaan profitabilitas, leverage, dan ukuran perusahaan sebagai variabel kontrol. Manajemen laba dalam penelitian ini diukur dengan menggunakan Eckel Index (1981). Penelitian ini menggunakan sampel perusahaan manufaktur yang terdaftar di Bursa Efek Indonesia tahun 2008-2011. Sampel diperoleh dengan menggunakan metode purposive sampling. Metode pengujian hipotesis yang digunakan adalah analisis regresi berganda dengan variabel dummy. Ada sebuah perusahaan 48 per tahun yang memenuhi kriteria sampel penelitian. Hasil penelitian ini menunjukkan bahwa komisaris independen, komite audit dan kepemilikan manajerial tidak berpengaruh signifikan memoderasi pengaruh manajemen laba pada pengungkapan tanggung jawab lingkungan perusahaan. Sementara itu, berpengaruh kepemilikan institusional secara signifikan. Dua dari tiga variabel kontrol yang digunakan dalam penelitian ini, yaitu profitabilitas dan leverage tidak memiliki pengaruh yang signifikan pada efek dari manajemen laba pada pengungkapan tanggung jawab lingkungan perusahaan, sedangkan pengaruh kepemilikan institusional memiliki pengaruh yang signifikan pada efek dari manajemen laba pengungkapan tanggung jawab lingkungan perusahaan.

Kata kunci: Manajemen Laba, Tanggung Jawab Lingkungan Perusahaan Pengungkapan, Corporate Governance.

PENDAHULUAN

Fungsi dan tugas manajemen adalah sebuah kepentingan di dalam manajemen yang merencanakan, melaksanakan dan mengendalikan pemanfaatan sumber daya 
keuangan dalam kegiatan entitas secara efektif dan efisien (Munawir 1986). Untuk mengendalikan aktivitas perusahaan, pihak manajemen tentunya lebih mengerti dan memahami keadaan-keadaan yang terjadi di perusahaannya. Manajer yang bertugas untuk mengendalikan aktivitas organisasi harus bertanggung jawab atas aktivitas yang dilakukannya terhadap unit perusahaan yang dipimpinnya kepada para stakeholders. Pertanggungjawaban manajemen bisa dilihat dari laporan keuangan perusahaan. lebih efisien. Seperti yang diungkapkan Rahmawati dan Dianita (2011), laporan keuangan merupakan alat utama bagi manajemen untuk menyampaikan informasi keuangan perusahaan. Penyampaian informasi keuangan perlu dilakukan untuk memenuhi tanggung jawab manajemen kepada pemilik perusahaan dan kepada para stakeholders yang tidak memiliki otoritas untuk mendapatkan informasi yang mereka butuhkan langsung dari perusahaan sumber.

Pendapatan memiliki relevansi yang tinggi jika dikaitkan dengan peningkatan atau penurunan harga saham dan dapat digunakan untuk memprediksi masa depan kinerja perusahaan. Para pemangku kepentingan sering menggunakan angka pendapatan sebagai dasar pengambilan keputusan ekonomi. Selain angka pendapatan, laba merupakan indikator kinerja perusahaan dan memiliki relevansi tinggi untuk kinerja perusahaan di masa depan dan. Akan tetapi, permasalahan terjadi ketika relevansi laba sebagai alat pengukur kinerja perusahaan dihadapkan dengan praktik manipulasi (earnings management) yang dilakukan oleh manager (Rahmawati dan Dianita 2011).

Salah satu konsekuensi fatal akibat tindakan manajemen yang memanipulasi laba adalah perusahaan akan kehilangan dukungan dan kepercayaan dari pemangku kepentingan, para stakeholders akan memberikan respon negatif dari investor dalam bentuk tekanan, sanksi dari regulator, ditinggalkan rekan kerja, boikot dari aktivis dan pemberitaan negatif media massa (Prior et al. 2008). Untuk itu manajer memiliki dorongan, untuk secara sukarela mengungkapkan informasi lingkungan untuk menarik investor yang ada atau potensial dan untuk meningkatkan citra perusahaan mereka, terutama ketika mereka melakukan earnings management (Sun et al. 2010). Manajer mencari sebuah strategi untuk mempertahankan reputasi perusahaan dan melindungi karirnya. Salah satu cara yang digunakan manajer sebagai strategi pertahanan diri adalah dengan mengeluarkan kebijakan yang tegas tentang corporate environmental responsibility disclosure.

Konflik keagenan terjadi ketika manajer mengambil keuntungan dengan memanipulasi earnings management untuk keuntungan mereka sendiri, maka corporate environmental responsibility disclosure merupakan sarana untuk melindungi pekerjaan mereka, dan untuk mengalihkan perhatian pemegang saham dari pemantauan aktivitas earnings management (Sun et al. 2010). Dalam penelitian ini, Sun et al. (2010) juga berpendapat bahwa manajer yang terlibat dalam praktek earnings management termotivasi untuk berperilaku proaktif dengan mencari persepsi dari pemegang saham dan beragam kelompok pemangku kepentingan dengan melaporkan pengungkapan sukarela seperti corporate environtmental responsibility disclosure dalam laporan tahunan dipandang perlu untuk menunjukkan kepada para stakeholders kepentingan kesadaran perusahaan untuk ikut serta dalam tanggung jawab sosial dan lingkungan.

Selain melalui program CSR, pengurangan earnings management yang dilakukan oleh manajemen dapat dilakukan dengan menggunakan mekanisme corporate governance. Corporate governance merupakan salah satu dasar dalam meningkatkan efisiensi ekonomis, yang meliputi hubungan antara manajemen perusahaan dan stakeholder. Corporate governance juga diperlukan untuk mengendalikan perilaku pengeola perusahaan agar bertindak dengan tidak hanya menguntungkan dirinya sendiri (Bangun dan Vincent 2008). Dari beberapa penelitian terdahulu menyebutkan bahwa mekanisme corporate governance memiliki 
pengaruh terhadap earnings management (Shah et al. 2009); Ugbede et al. (2013). Terdapat beberapa mekanisme corporate governance yang dapat mengendalikan perilaku earnings management yang dilakukan oleh manajemen disebabkan karena adanya asimetri informasi dan conflict of interest. Pertama, proporsi komisaris independen mempengaruhi tindakan earnings management (Abed et al. 2012). Kedua, jumlah komite audit yang aktif dalam menghambat tindakan manajemen untuk melakukan kegiatan earnings management (Veronica dan Bachtiar 2005). Ketiga, kepemilikan institusional yang signifikan dapat mengurangi motivasi manajer untuk melakukan earnings management (Midiastuty dan Mahfoedz 2003). Keempat, proporsi kepemilikan manajerial yang semakin tinggi akan meningkatkan motivasi manajer untuk meningkatkan usaha dalam rangka memaksimalkan nilai perusahaan.

Perbedaan dari berbagai hasil penelitian tersebut maka rumusan masalah pada penelitian ini adalah apakah mekanisme corporate governance dapat memoderasi pengaruh earnings management terhadap corporate environmental disclosure (CED) di Indonesia?

\section{T I N J U A N P US T A KA D A N PENGEMBANGAN HIPOTESIS \\ Teori Agensi (Agency Theory)}

Teori agensi atau sering juga disebut dengan teori keagenan karena mampu menjelaskan hubungan antara principal (pemberi wewenang) dalam hal ini adalah investor dengan agen (penerima wewenang) dalam hal ini adalah manajer. Dalam hubungan keagenan terdapat konflik kepentingan antara principal dan agen yang terjadi karena kemungkinan agen bertindak tidak sesuai dengan kepentingan principal, sehingga muncul adanya biaya keagenan (agency cost) (Jensen dan Meckling 1976). Pihak manajemen (agen) diwajibkan untuk memberikan laporan periodik atas kinerjanya kepada principal, kemudian principal akan menilai kinerja agennya berdasarkan laporan keuangan yang disampaikannya (Benardi et al. 2009), sehingga laporan keuangan dapat dijadikan sebagai sarana transparasi dan akuntabilitas atas kinerja perusahaan (agen) kepada principal. Mekanisme good corporate governance sebagai sistem yang mengatur dan mengendalikan perusahaan diharapkan dapat memberikan kepercayaan kepada manajemen dalam rangka mengelola kekayaan para pemegang saham, sehingga dapat meminimalisir konflik kepentingan yang terjadi antara principal (pemegang saham) dan agen (manajemen) (Waryanto 2010).

\section{Earnings Management (Manajemen Laba)}

Earnings management merupakan upaya manajer untuk mengintervensi atau mempengaruhi informasi-informasi dalam laporan keuangan dengan tujuan untuk mengelabuhi stakeholders yang ingin mengetahui kinerja dan kondisi perusahaan (Sulistyanto 2008). Hal ini bisa saja dilakukan oleh manajer untuk memperoleh keuntungan pribadi dengan memanipulasi laba. Tindakan manajerial seperti ini dapat menyesatkan stakeholders tentang nilai perusahaan dan posisi keuangan (Sun et al. 2010).

\section{Corporate Social Responsibility (CSR)}

Tanggung jawab sosial dimulai sejak tahun 1960-an dimana secara global, masyarakat dunia baru saja pulih dari Perang dunia 1 dan II. Menurut cara pandang tradisional, tanggung jawab tradisional perusahaan lebih didasarkan pada aktivitas yang bersifat karikatif. Pada saat itu social responsibility masih didominasi oleh kegiatan karikatif jangka pendek, dan merupakan sikap murah hati para investor (Hadi 2011). Wujud tanggung jawab sosial hanya bersifat karikatif dan insidental, yang bergantung pada kesadaran dan keinginan investor. Kemudian pada era 1970-an praktik tanggung jawab sosial mengalami perkembangan seperti dengan dimulainya berbagai kegiatan yang berorientasi pada pemberdayaan masyarakat, dimana masyarakat dan lingkungan sebagai sentral pertimbangan 
munculnya kegiatan. Kegiatan-kegiatan sosial yang ada bukan hanya ditujukan untuk derma (kebajikan investor) ( Hadi 2011).

Pada era 1990-an hingga sekarang, sudah timbul kesadaran dari masingmasing perusahaan untuk melakukan tanggung jawab sosial. Tanggung jawab sosial dan lingkungan adalah komitmen perseroan untuk berperan serta dalam pembangunan ekonomi berkelanjutan guna meningkatkan kehidupan dan lingkungan yang bermanfaat, baik bagi perseroan sendiri maupun masyarakat umumnya (UU No. 40 Tahun 2007 Tentang Perseroan Terbatas).

\section{Corporate Environmental Responsibility Disclosure (CERD)}

Menurut Ghozali dan Chairi (2003) kata disclosure, jika dikaitkan dengan laporan keuangan, berarti bahwa laporan keuangan harus memberikan informasi dan penjelasan yang cukup mengenai hasil aktivitas suatu unit usaha. Menurut Dahlan (2003) pengungkapan yang dilakukan perusahaan terbagi atas dua jenis yaitu, voluntary disclosure dan mandatory disclosure. Voluntary disclosure adalah pengungkapan berbagai informasi yang berkaitan dengan aktivitas/keadaan perusahaan secara sukarela. Meskipun pada kenyataannya pengungkapan secara sukarela tidak benar-benar terjadi, karena perusahaan cenderung untuk menyembunyikan informasi yang sifatnya dapat menurunkan arus kas, dan tentunya akan menyebabkan kerugian pada perusahaan. Oleh karena itu, manajer hanya mengungkapkan informasi yang baik mengenai perusahaannya. Jenis pengungkapan lainnya adalah mandatory disclosure yaitu pengungkapan informasi perusahaan yang bersifat wajib dan dinyatakan dengan peraturan hukum. Pengungkapan yang bersifat mandatory akan mendapat sorotan dan kontrol dari lembaga yang berwenang. Selain itu, terdapat standar yang menjamin kesamaan bentuk secara relatif dalam praktik pelaporan dan terdapat persyaratan minimum yang harus dipenuhi.
Dalam penelitian ini digunakan Indeks GRI (Global Reporting Initiative) untuk menilai environmental disclosure. Semua dokumen berdasarkan kerangka pelaporan GRI dikembangkan melalui sebuah proses pencapaian konsensus lewat dialog di antara para pemangku kepentingan yang berasal dari perusahaan, komunitas investor, pekerja, masyarakat sipil, akuntan, akademisi, dan pihak lainnya. Kerangka pelaporan GRI ditujukan sebagai sebuah kerangka yang dapat diterima umum dalam melaporkan kinerja ekonomi, lingkungan, dan sosial dari sebuah organisasi serta kerangka ini didesain fleksibel, sehingga bisa diterima di segala macam bentuk organisasi (Pedoman Laporan Keberlanjutan 2006).

\section{Good Corporate Governance (GCG)}

Corporate governance menurut OECD (Organization for Economic Coorperation and Development) adalah

"Corporate governance is the system by which business corporations are directed and controlled. The corporate governance structure specifies the distribution of the right and responsibilities among different participants in the corporation. Such as the board, managers, shareholders, and other stakeholderss" (Tim Studi Pengkajian Penerapan Prinsip-prinsip OECD 2004 dalam peraturan Bapepam mengenai Corporate governance 2006)

OECD melihat corporate governance sebagai sebuah sistem untuk mengarahkan dan mengendalikan perusahaan. Penerapan corporate governance akan berhasil jika mematuhi prinsip yang berlaku. Menurut pedoman umum good corporate governanceIndonesia yang dikemukakan oleh Komite Nasional Kebijakan Governance, corporate governance memiliki prinsip sebagai berikut:

Transparancy, untuk menjaga objektivitas dalam menjalankan bisnis, perusahaan harus menyediakan informasi yang relevan dengan cara yang mudah dipahami dan bisa diakses oleh pemangku kepentingan.

Accountability, sebuah perusahaan harus 
dikelola secara benar, terukur dan sesuai dengan kepentingan perusahaan dengan tetap memper-hitungkan kepentingan pemegang saham dan pemangku kepentingan lain, karena perusahaan harus dapat mempertanggungjawabkan kinerjanya secara transparan dan wajar.

Responsibility, perusahaan harus melaksanakan tanggung jawab terhadap masyarakat dan lingkungan serta darus mematuhi peraturan perundang-undangan yang berlaku.

Independency, sebuah perusahaan harus dikelola secara independen, sehingga masing-masing organ perusahaan tidak saling mendominasi dan dapat diintervensi oleh pihak lain.

Fairness, dalam melaksanakan kegiatannya, perusahaan harus memperhatikan kepentingan pemegang saham dan stakeholders lainnya berdasarkan asas kewajaran dan kesetaraan (Pedoman Umum Good Corporate governance Indonesia 2006).

Dalam menjalankan corporate governance tentu memiliki mekanisme atau cara kerja yang terstruktur untuk memenuhi persyaratan tertentu. Mekanisme corporate governance merupakan suatu aturan, prosedur utama dan hubungan yang jelas antara pihak yang mengambil keputusan dengan baik yang melakukan pengawasan terhadap keputusan tersebut. Menurut pedoman umum goodcorporate governance Indonesia, organ perusahaan yang terdiri dari Rapat Umum Pemegang Saham (RUPS), Dewan Komisaris dan Direksi, memiliki peran penting dalam pelaksanaan good corporate governance secara efektif.

\section{Earnings Management dan Corporate Environmental Responsibility Disclosure}

Perbedaan informasi antara manajemen dan pemilik perusahaan dapat memberikan kesempatan kepada manajer untuk melakukan manajemen laba sehingga memberikan informasi yang tidak sesuai terkait dengan kinerja dan potensi masa depan perusahaan di dalam pelaporan keuangan perusahaan (Djuitaningsih dan Marsyah 2012). Literatur manajemen laba menunjukkan bahwa pasar modal, kontrak pengaturan, dan pertimbangan peraturan menginduksi manajer untuk memanipulasi laporan pendapatan. Prior et al. (2008) berpendapat bahwa tindakan manajerial ini sengaja direncanakan untuk menyamarkan nilai riil dari aset perusahaan, transaksi yang terjadi, atau posisi keuangan. Tindakan manajemen laba yang dilakukan manajemen ini memiliki konsekuensi negatif bagi pemegang saham, karyawan, masyarakat di mana perusahaan bekerja, dan manajer, keamanan kerja, dan karir. Selain itu Prior et al. (2008) berpendapat bahwa praktik manajemen laba merusak kepentingan kolektif stakeholder, kemudian manajer yang memanipulasi laba dapat menangani aktivisme stakeholder dan kewaspadaan dengan beralih ke praktik CSR.

Manajer yang terlibat dalam praktik earnings management termotivasi untuk berperilaku proaktif dengan mencari persepsi dari pemegang saham dan beragam kelompok pemangku kepentingan bahwa mereka mengambil tindakan untuk kinerja yang optimal. Dengan demikian, pengungkapan sukarela dalam laporan tahunan, seperti CED dipandang perlu untuk menunjukkan kepada para pemangku kepentingan kesadaran perusahaan dari kepentingan yang lebih luas (Sun et al. 2010). Selain itu, CED dianggap sebagai sarana untuk mengalihkan perhatian pemegang saham dari pemantauan aktivitas earnings management yang dilakukan oleh manajer (Sun et al. 2010). Maka, peneliti dapat menarik hipotesis pertama:

H1: Earnings management berpengaruh terhadap corporate environmental responsibility disclosure.

\section{Mekanisme Corporate Governance dan Corporate Environmental Responsibility Disclosure}

Corporate governance adalah prinsip yang mengarahakan dan mengendalikan perusahaan agar mencapai keseimbangan antar kekuatan serta kewenangan perusahaan dalam memberikan pertanggungjawaban kepada shareholders 


\begin{abstract}
khususnya dan stakeholders pada umumnya (Cadbury Committee 1999). Corporate governance memiliki berbagai faktor penentu yang gunanya untuk mengendalikan perusahaan untuk mencapai kesinambungan (Setyarini dan Paramitha 2011).
\end{abstract}

\section{Pengaruh Earnings Management, Komisaris Independen dan Corporate Environmental Responsibility Disclosure}

Adanya asimetri informasi mengakibatkan manajer memiliki kesempatan melakukan tindakan earnings management untuk memberikan informasi yang tidak sesuai dengan kinerja dan potensi masa depan perusahaan di dalam pelaporan keuangan perusahaan (Healy dan Wahlen 1999). Komisaris Independen merupakan anggota komisaris yang tidak terafiliasi dengan direksi, anggota dewan komisaris lainnya dan pemegang saham pengendali, serta bebas dari hubungan bisnis atau hubungan lainnya yang dapat mempengaruhi kemampuannya untuk mengawasi aktivitas pengelolaan perusahaan (KNKG 2006). Herawaty (2008) menyatakan bahwa komisaris independen dapat memonitor manajemen dalam rangka menyelaraskan perbedaan kepentingan antara pemilik dan manajemen. Akhtaruddin et al. (2009) menyatakan bahwa semakin besar ukuran dewan komisarsm maka komposisi pengalaman dan keahlian yang dimiliki dewan koisaris semakin meningkat, sehingga dapat melakukan aktivitas monitoring dengan lebih baik. Dengan proses monitoring yang lebih baik, maka memungkinkan manajer melakukan kecurangan dalam manajemen laba juga dapat diminimalkan.

H2: Proporsi komisaris independen berperngaruh signifikan terhadap pengaruh earnings management terhadap corporate environmental responsibility disclosure.

Earnings Management, Jumlah Anggota Komite Audit dan Corporate Environmental Responsibility Disclosure

Kelonggaran yang diberikan atas pemilihan metode akuntansi dapat dimanfaatkan manajemen untuk menghasilkan laba yang berbeda, sehingga praktik ini dapat memberikan dampak terhadap kualitas laba yang dihasilkan (Boediono 2005). Handajani et al (2008) mengungkapkan bahwa keberadaan komite audit dapat mempengaruhi pengungkapan yang dilakukan perusahaan secara signifikan. Komite audit membantu menjamin pengungkapan dan sistem pangendalian dengan baik. Dengan demikian diharapkan semakin besarnya ukuran komite audit suatu perusahaan, pengawasan yang dilakukan semakin membaik dan kualitas informasi sosial yang dilakukan semakin meningkat dan semakin luas (Djuitaningsih dan Marsyah 2012). Fatayaningrum (2011) menyatakan bahwa tingkat jumlah pertemuan yang dilakukan oleh komite audit dapat menjamin bahwa pelaksanaan pengawasan terhadap manajemen untuk melakukan kecurangan akan berjalan secara efektif, sehingga peluang manajemen untuk melakukan kecurangan dengan menyembunyikan informasu dapat diminimalisasi.

H3:Jumlah anggota komite audit berpengaruh signifikan terhadap pengaruh earnings management terhadap corporate environmental responsibility disclosure.

Earnings Management, Kepemilikan Institusi dan Corporate Environmental Responsibility Disclosure

Kepemilikan institusional memiliki kemampuan untuk mengendalikan pihak manajemen melalui proses monitoring secara efektif sehingga dapat mengurangi manajemen laba (Bangun dan Vincent 2008). Presentase saham tertentu yang dimiliki oleh institusi dapat memengaruhi proses penyusunan laporan keuangan yang tidak menutup kemungkinan terdapat akrualisasi sesuai kepentingan pihak manajemen (Boediono 2005). Tindakan pengawasan perusahaan oleh pihak investor institusional dapat mendorong manajer untuk lebih memfokuskan perhatiannya terhadap kinerja perusahaan sehingga akan mengurangi perilaku oportunistik (mementingkan diri sendiri) 
(Tehranian et al. 2006). Dengan proses monitoring yang dilakukan oleh pemilik saham oleh institusi diharapkan dapat mengurangi kegiatan manajemen dalam memanipulasi laba.

H4: Institusional ownership berpengaruh signifikan terhadap pengaruh earnings management terhadap corporate environmental responsibility disclosure.

\section{Earnings Management, Kepemilikan Manajerial dan Corporate Environmental Responsibility Disclosure}

Semakin besar proporsi kepemilikan manajemen pada perusahaan, maka manajemen akan cenderung berusaha lebih giat untuk kepentingan pemegang saham yang tidak lain adalah dirinya sendiri (Ross et al. 2008). Dari sudut pandang teori akuntansi, manajemen laba sangat ditentukan oleh motivasi manajemen perusahaan. Bangun dan Vincent (2008) menyatakan bahwa motivasi yang berbeda akan menghasilkan besaran yang berbeda, seperti antara manajer yang juga sekaligus pemegang saham dan manajer yangb tidak sebagai pemegang saham. Hal ini akan mempengaruhi manajemen laba, sebab kepemilikan seorang manajer akan ikut menentukan kebijakan dan pengambilan keputusan terhadap metode akuntansi yang diterapkan pada perusahaan yang mereka kelola. Dengan adanya kepemilikan saham oleh manajerial diharapkan dapat mengurangi praktik earnings management oleh manajer. Dari paparan tersebut maka hipotesis keempat:

H5: Managerial ownership berpengaruh signifikan terhadap pengaruh earnings management terhadap corporate environmental responsibility disclosure.

\section{METODE PENELITIAN}

\section{Populasi dan Sampel}

Populasi dalam penelitian ini adalah perusahaan yang beroperasi di Indonesia dan terdaftar di Bursa Efek Indonesia. Pemilihan sampel dalam penelitian ini menggunakan metode purposive sampling. Sampel dalam penelitian ini adalah perusahaan manufaktur yang terdaftar di
Bursa efek Indonesia (BEI) pada tahun 2008 -2011, karena pada tanggal 20 Juli 2007 telah dikeluarkan Undang-undang Perseroan Terbatas (PT) Nomor 40 yang didalamnya memuat kewajiban pelaksanaan dan pengungkapan tanggung jawab sosial dan lingkungan yang baru berlaku pada akhir tahun 2007. Perusahaan -perusahaan tersebut harus memiliki kriteria sebagai berikut: 1) Perusahaan manufaktur yang terdaftar di BEI dan mempublikasikan laporan keuangan auditan secara konsisten dan lengkap dari tahun 2008-2011. 2) Menyediakan laporan tahunan maupun sustainability reporting lengkap selama tahun 2008-2011. 3) Melakukan pengungkapan lingkungan lengkap selama tahun 2008-2011. 4) Perusahaan tersebut tidak dalam kondisi suspended atau delisting selama tahun 2008-2011. 5) Perusahaan memiliki kelengkapan data mengenai komisaris independen, komite audit, kepemilikan intitusional dan kepemilikan manajerial.

\section{Jenis dan Sumber Data}

Data yang digunakan dalam penelitian ini adalah data sekunder yang merupakan data kuantitatif. Data sekunder dalam penelitian ini diperoleh melalui Bursa Efek Indonesia (BEI), internet/website, dan website perusahaan. Pengumpulan data dilakukan dengan cara menelusuri laporan tahunan yang terpilih menjadi sampel. Instrumen penelitian Global Reporting Initiative (GRI) berupa checklist atau daftar pernyataanpernyataan yang berisi item-item pengungkapan informasi lingkungan perusahaan digunakan sebagai panduan pengumpulan data.

Sumber perolehan data dengan cara mengumpulkan informasi yang terkait laporan tahunan, laporan keuangan tahunan (neraca, laporan laba-rugi, laporan arus kas, dan catatan atas laporan keuangan) perusahaan manufaktur yang termasuk dalam kriteria sampel penelitian.

\section{Definisi Operasional dan Pengukuran}

Variabel dalam penelitian ini terdiri dari variabel dependen, variabel independen, variabel moderator dan variabel kontrol. 
Variabel dependen dalam penelitian ini adalah corporate environmental responsibility disclosure. Variabel independen dalam penelitian ini adalah earnings management. Variabel moderator dalam penelitian ini adalah mekanisme corporate governance yang diproksikan oleh proporsi komisaris independen, jumlah komite audit, kepemilikan institusional, dan kepemilikan manajerial, sedangkan variabel kontrol terdiri dari ukuran perusahaan, profitabilitas, dan leverage.

Variabel independen yang digunakan dalam penelitian ini adalah earnings management (manajemen laba). Earnings management merupakan perilaku oportunistik manajer guna memaksimalkan keuntungan mereka sendiri. Dalam penelitian ini, earnings management menggunakan proksi indeks Eckel (1981), yang mengelompokan perusahaan menjadi dua kelompok, yaitu: termasuk perusahaan yang melakukan earnings management atau perusahaan yang tidak melakukan earnings management. Menurut Christiana (2012) indeks eckel merupakan alat pengklasifikasian yang tepat untuk memisahkan perusahaan perata laba dengan perusahaan bukan perata laba. Indeks eckel dihitung dengan rumus:

$$
\text { Indeks eckel }=\frac{\mathrm{CV} \Delta \mathrm{I}}{\mathrm{CV} \Delta \mathrm{S}}
$$

Dimana $\mathrm{CV} \Delta \mathrm{I}$ dan $\mathrm{CV} \Delta \mathrm{S}$ dapat dihitung sebagai berikut:

$$
\begin{gathered}
\Delta \mathrm{S}=\frac{\mathrm{S}_{\mathrm{t}}-\mathrm{S}_{\mathrm{t}-1}}{\mathrm{~S}_{\mathrm{t}-1}} \quad \Delta \mathrm{I}=\frac{\mathrm{I}_{\mathrm{t}}-\mathrm{I}_{\mathrm{t}-1}}{\mathrm{I}_{\mathrm{t}-1}} \\
\mathrm{CV} \Delta \mathrm{I}=\sqrt{\mathrm{n}-1}): \Delta \mathrm{I} \\
\left.\mathrm{CV} \Delta \mathrm{S}=\sqrt{\left(\frac{\Sigma(\Delta \mathrm{I}-\Delta \overline{\mathrm{I}})^{2}}{\mathrm{n}-\Delta \hat{\mathrm{S}})^{2}}\right.}\right): \Delta \mathrm{S}-1
\end{gathered}
$$

Dengan penjelasan ketika indeks Eckel kurang dari 1 maka perusahaan dikategorikan melakukan earnings management. Apabila perusahaan
Keterangan:

$\mathrm{CV} \Delta \mathrm{S} \quad$ Koefisien variasi untuk perubahan penjualan

$\mathrm{CV} \Delta \mathrm{I} \quad$ Koefisien variasi untuk perubahan laba

$\Delta \mathrm{S} \quad$ Perubahan penjualan dalam satu periode

$\Delta I \quad$ Perubahan laba dalam satu periode

$\Delta \hat{\mathrm{S}} \quad$ Rata-rata perubahan penjualan

$\Delta \overline{\mathrm{I}} \quad$ Rata-rata perubahan laba

n JumlahTahun

melakukan praktik earnings management, maka akan diberi status 1 , sedangkan jika perusahaan tidak melakukan praktik earnings management akan diberi status 0 .

Variabel dependen yang digunakan dalam penelitian ini adalah corporate environmental responsibility disclosure (CERD). CERD dapat diperoleh dari sustainability report (laporan keberlanjutan). CERD dalam penelitian ini diukur dengan menggunakan indeks Global Reporting Initiative (GRI). Indeks GRI memiliki format dan isi laporan yang paling lengkap dalam menyediakan informasi. Global Reporting Initiatif menjabarkan dampak operasi perusahaan terhadap 1, pengungkapan item CED dilakukan dengan menggunakan rumus sebagai berikut:

$$
\mathrm{N}=\frac{\text { Jumlah item yang diungkapkan perusahaan }}{\text { Jumlah item pengungkapan lingkungan GRI }}
$$

\section{Variabel Moderator}

Variabel Moderator merupakan variabel yang memengaruhi hubungan langsung antara variabel independen dan variabel dependen, pengaruh itu dapat memperkuat atau memperlemah hubungan antara variabel terikat dan variabel bebas (Sanusi 2011). Corporate governance merupakan variabel moderasi dalam penelitian ini. Definisi corporate governance menurut OECD (Organization for Economic Cooperation and Development) (Dikutip 
oleh Solihin 2009) adalah suatu sistem untuk mengarahkan dan mengendalikan perusahaan. Struktur corporate governance menetapkan distribusi hak dan kewajiban di antara berbagai pihak yang terlibat dalam suatu korporasi seperti dewan direksi, para manajer, para pemegang saham, dan para pemangku kepentingan lainnya. Mekanisme corporate governance dalam penelitian ini diproksikan dengan proporsi komisaris independen, jumlah anggota komite audit, kepemilikan institusional, dan kepemilikan manajerial.

Komisaris independen adalah anggota dewan komisaris yang tidak berafiliasi dengan manajemen, anggota dewan komisaris lainnya dan pemegang saham pemegang saham pengendali, serta bebas dari hubungan bisnis atau hubungan lainnya yang dapat mempengaruhi kemampuannya untuk bertindak independen atau bertindak semata-mata demi kepentingan perusahaan (KNKG 2006). Proporsi komisaris independen dihitung dengan rumus:

$$
\begin{aligned}
& \begin{array}{l}
\text { Proporsi } \\
\text { komisaris } \\
\text { independen }
\end{array}= \\
& \cline { 2 - 2 }
\end{aligned}
$$

Komite audit adalah komite yang dibentuk dan bertanggung jawab kepada komisaris dalam membantu melaksanakan tugas dan fungsi dewan komisaris, seperti melakukan penelaahan-penelaahan atas informasi keuangan yang akan dikeluarkan perusahaan, ketaatan terhadap peraturan perundang-undangan yang berhubungan dengan kegiatan perusahaan, pemeriksaan oleh auditor internal dan mengawasi pelaksanaan tindak lanjut oleh direksi atas temuan auditor internal, aktivitas manajemen resiko yang dilakukan oleh direksi, jika perusahaan tidak memiliki fungsi pemantau resiko di bawah dewan komisaris, pengaduan yang berkaitan dengan proses akuntansi dan pelaporan keuangan perusahaan, memberikan pendapat independen dalam hal terjadi perbedaan pendapat antara manajemen dan akuntan atas jasa yang diberikan, memberikan rekomendasi kepada komisaris independen tentang penunjukkan akuntan yang didasarkan pada independensi ruang lingkup penugasan dan fee, serta menjaga kerahasiaan dokumen, data, dan informasi perusahaan (Keputusan Ketua Bapepam dan LK Nomor Kep-634/BL/2012). Komite audit dalam penelitian ini, dihitung dengan menghitung jumlah anggota komite audit.

Kepemilikan institusional adalah jumlah saham yang dimiliki oleh investor institusi terhadap total saham luar biasa (Rahmawati dan Dianita 2011). Presentase kepemilikan institusional memiliki kemampuan untuk mengendalikan pihak manajemen melalui proses monitoring secara efektif sehingga dapat mengurangi manajemen laba (earnings management). Presentase saham tertentu yang dimiliki oleh institusi dapat memengaruhi proses penyusunan laporan keuangan yang tidak menutup kemungkinan terdapat akrualisasi sesuai kepentingan pihak manajemen (Boediono 2005). Untuk mengukur kepemilikan ini, indikator yang digunakan adalah persentase jumlah saham yang dimiliki pihak institusi dibandingkan seluruh jumlah modal saham yang beredar.

Kepemilikan manajerial adalah jumlah kepemilikan saham oleh pihak manajemen dari seluruh modal saham perusahaan yang dikelola. Manajemen disini merupakan pemilik saham dari dalam perusahaan pada tingkat manajerial (Terzaghi 2012). Indikator untuk mengukur kepemilikan manajerial adalah presentase jumlah saham yang dimiliki pihak manajerial dibandingkan seluruh jumlah modal saham yang beredar.

\section{Variabel Kontrol}

Variabel kontrol adalah variabel yang dikendalikan atau dibuat konstan sehingga hubungan variabel bebas terhadap variabel terikat dan tidak dipengaruhi oleh faktor luar yang tidak diteliti. Variabel kontrol dalam penelitian ini adalah ukuran perusahaan, profitabilitas, dan leverage. Profitabilitas diukur dengan menggunakan ukuran ROA, sedangkan leverage dihitung dengan menggunakan presentase perbandingan antara total utang dan total 
aset, dan ukuran perusahaan diukur dengan menggunakan logaritma dari nilai buku total aset.

\section{METODE ANALISIS DATA}

Metode analisis dalam penelitian ini menggunakan analisis regresi berganda dengan variabel dummy. Analisis regresi berganda dimaksudkan untuk menguji pengaruh simultan dari beberapa variabel bebas terhadap satu variabel terikat. Dalam penelitian ini, sebelum memasukan variabel moderasi kedalam uji regresi berganda dengan variabel dummy, maka terlebih dulu dilakukan pengujian langsung antara pengaruh variabel independen terhadap variabel dependen dengan model penelitian adalah sebagai berikut:

Model 1:

$$
\begin{gathered}
\text { PCERit } \\
\beta_{3} \text { LEVit }+\beta_{4} \text { ROAit }
\end{gathered}
$$

Kemudian, setelah melakukan pengujian langsung antara variabel dependen dengan independen, maka variabel moderator bisa dimasukkan ke dalam model regresi adalah sebagai berikut:

\section{Model 2:}

$$
\begin{aligned}
& \text { PCERit }=\alpha+\beta_{1} \text { IEit }+\beta_{2} \text { INDEPit }+ \\
& \beta_{3} \text { AUDCOMit }+\beta_{4} \text { IOit }+\beta_{5} \text { MOit }+ \\
& \beta_{6} \text { IEit"INDEPit }+\beta_{7} \text { IEit *AUDCOMit }+\beta_{8} \text { I } \\
& \text { Eit"IOit }+\beta_{9} \text { IEit"MOit }+\beta_{10} \text { SIZEit }+ \\
& \beta_{11} \text { LEVit }+\beta_{12} \text { ROAit }
\end{aligned}
$$

\section{ANALISIS DAN PEMBAHASAN}

\section{Analisis Koefisien Determinasi $\left(\mathbf{R}^{2}\right)$}

Hasil analisis determinasi pada penelitian ini, dapat dilihat pada tabel 1 dan tabel 2 di bawah ini:

Tabel 1

Hasil Analisis Determinasi $\left(\mathrm{R}^{2}\right)$ Model 1

\begin{tabular}{ccccc}
\hline Model & $\mathrm{R}$ & $\begin{array}{c}\mathrm{R} \\
\text { Square }\end{array}$ & $\begin{array}{c}\text { Adj.R } \\
\text { Square }\end{array}$ & $\begin{array}{c}\text { Std. Error } \\
\text { of the } \\
\text { Estimate }\end{array}$ \\
\hline $\mathbf{1}$ & $.410^{\mathrm{a}}$ & .168 & .150 & .15799 \\
\hline
\end{tabular}

Berdasarkan tabel 1, nilai $\mathrm{R}^{2}$ yang disesuaikan memperoleh nilai 0.150 atau $15 \%$, yang berarti 15\% CERD dipengaruhi oleh earnings management yang dikontrol oleh firm size, leverage dan ROA,
Tabel 2

Hasil Analisis Determinasi $\left(\mathrm{R}^{2}\right)$ Model 2

\begin{tabular}{lcrrr}
\hline Model & $\mathrm{R}$ & $\begin{array}{c}\mathrm{R} \\
\text { Square }\end{array}$ & $\begin{array}{c}\text { Adj R } \\
\text { Square }\end{array}$ & $\begin{array}{c}\text { Std. Error } \\
\text { of the } \\
\text { Estimate }\end{array}$ \\
\hline $\mathbf{1}$ & $.511^{\mathrm{a}}$ & .261 & .211 & .15221 \\
\hline
\end{tabular}

sedangkan sisanya sebesar $85 \%$ dipengaruhi oleh faktor lain diluar model. Sedangkan pada tabel 2, nilai $\mathrm{R}$ yang disesuaikan adalah sebesar 0,211 atau $21,1 \%$, yang berarti $21,1 \%$ CERD dipengaruhi oleh earnings management, proporsi komisaris independen, jumlah anggota komite audit, institusional ownership, managerial ownership, interaksi EM dan proporsi komisaris independen, interaksi EM dan jumlah anggota komite audit, interaksi EM dan Institusional Ownership, Interaksi EM dan Managerial Ownership, Size, Leverage, dan ROA. Sisanya atau 79,9\% dipengaruhi oleh faktor lain di luar model.

\section{Uji Signifikasi Simultan (Uji F)}

Berikut adalah hasil perhitungan uji signifikasi simultan dengan menggunakan spss:

Tabel 3

Hasil Uji Signifikasi Simultan (Uji F) Model 1

\begin{tabular}{lccccc}
\hline Model & $\begin{array}{c}\text { Sum } \\
\text { of } \\
\text { Squa } \\
\text { res }\end{array}$ & Df & $\begin{array}{c}\text { Mea } \\
\text { Squa } \\
\text { re }\end{array}$ & F & Sig. \\
\hline $\mathbf{1}$ Regressi & & & & & \\
$\begin{array}{l}\text { on } \\
\text { Residual }\end{array}$ & .942 & 4 & .235 & 9.434 & .000 \\
Total & 4.67 & 187 & .025 & & \\
\hline
\end{tabular}

Tabel 4

Hasil Uji Signifikasi Simultan (Uji F) Model 2

\begin{tabular}{cccccc}
\hline Model & $\begin{array}{c}\text { Sum } \\
\text { of } \\
\text { Squar } \\
\text { es }\end{array}$ & Df & $\begin{array}{c}\text { Mean } \\
\text { Squa } \\
\text { re }\end{array}$ & F & Sig. \\
\hline 1 Regressi \\
$\begin{array}{l}\text { on } \\
\text { Residual }\end{array}$ & 1.463 & 12 & .122 & 5.261 & $.000^{\text {a }}$ \\
$\begin{array}{l}\text { Total } \\
\text { Tota }\end{array}$ & 179 & .023 & & \\
\hline
\end{tabular}

Berdasarkan tabel 3 nilai $\mathrm{F}$ hitung sebesar 9.434 dengan probabilitas 0,000 (pvalue $<0,005$ ). Maka dapat disimpulkan bah- 
wa earnings management, size, leverage, dan ROA secara bersama-sama berpengaruh terhadap CERD. Sedangkan pada model 2, menunjukkan nilai $\mathrm{F}$ sebesar 5,261 dengan probabilitas 0,000 (p-value $<$ 0,005). Maka, dapat disimpulkan bahwa earnings management, proporsi komisaris independen, jumlah anggota komite audit, institusional ownership, managerial ownership, interaksi EM dan proporsi komisaris independen, interaksi EM dan jumlah anggota komite audit, interaksi EM dan Institusional Ownership, Interaksi EM dan Managerial Ownership, Size, Leverage, dan ROA secara bersama-sama berpengaruh terhadap CERD. Tabel 5 dan tabel 6 di bawah ini merupakan tabel hasil uji signifikasi parsial (Uji t) adalah sebagai berikut:

Tabel 5

Hasil Uji Signifikasi Parsial (Uji t) Model 1

\begin{tabular}{|c|c|c|c|c|c|}
\hline Model & $\begin{array}{l}\text { Unstc } \\
\text { B }\end{array}$ & $\begin{array}{l}\text { Coef. } \\
\text { Std. } \\
\text { Error } \\
\end{array}$ & $\begin{array}{l}\text { Std } \\
\text { Coef. } \\
\text { Beta }\end{array}$ & $T$ & Sig. \\
\hline $\begin{array}{ll}1 & \\
& \text { (Const } \\
& \text { ant) }\end{array}$ & -.680 & .173 & & -3.942 & .000 \\
\hline EM & -.027 & .023 & -.079 & -1.174 & .242 \\
\hline SIZE & .079 & .014 & .373 & 5.533 & .000 \\
\hline LEV & -.007 & .014 & -.034 & -.514 & .608 \\
\hline ROA & .015 & .009 & .116 & 1.709 & .089 \\
\hline
\end{tabular}

Dari tabel 5 menunjukkan bahwa earnings management berpengaruh langsung terhadap CERD. Sedangkan pada tabel 6 menunjukkan bahwa hanya ada dua variabel yang berpengaruh signifikan terhadap corporate environmental responsibility disclosure (CERD) yaitu variabel interaksi antara earnings management dan institusional ownership dengan nilai signifikasi 0,007 dan Size (Ukuran Perusahaan) yang berperan sebagai variabel kontrol dengan nilai signifikasi 0,000 .
Tabel 6

Hasil Uji Signifikasi Parsial (Uji t) Model 2

\begin{tabular}{|c|c|c|c|c|c|}
\hline \multirow{2}{*}{$\begin{array}{l}\text { Model } \\
1 \text { (Cons }\end{array}$} & \multicolumn{2}{|c|}{ Unstd Coef. } & \multirow{2}{*}{$\begin{array}{l}\text { Std. } \\
\text { Coef } \\
\text { Beta }\end{array}$} & \multirow[b]{2}{*}{$\mathrm{T}$} & \multirow[b]{2}{*}{ Sig. } \\
\hline & B & $\begin{array}{l}\text { Std. } \\
\text { Error }\end{array}$ & & & \\
\hline $\begin{array}{l}\text { (Cons } \\
\text { tant) }\end{array}$ & -.154 & .261 & & -.591 & .556 \\
\hline$E M$ & .004 & .228 & .012 & .018 & .986 \\
\hline INDEP & -.149 & .155 & -.084 & -.959 & .339 \\
\hline $\begin{array}{l}\text { AUDC } \\
\text { OM }\end{array}$ & -.079 & .042 & -.184 & -1.864 & .064 \\
\hline IO & .000 & .001 & .021 & .192 & .848 \\
\hline MO & -.005 & .003 & -.213 & -1.739 & .084 \\
\hline IE & .360 & .243 & .434 & 1.479 & .141 \\
\hline EM_A & & & & & \\
\hline UDCO & .040 & .057 & .374 & .709 & .479 \\
\hline $\mathrm{M}$ & & & & & \\
\hline EM_IO & -.004 & .002 & -.926 & -2.732 & .007 \\
\hline EM_MO & .001 & .004 & .038 & .318 & .751 \\
\hline SIZE & .061 & .016 & .288 & 3.814 & .000 \\
\hline LEV & -.014 & .014 & -.067 & -1.007 & .315 \\
\hline ROA & .013 & .009 & .099 & 1.507 & .134 \\
\hline
\end{tabular}

\section{Hipotesis Pertama}

Hipotesis pertama dalam penelitian ini bertujuan untuk mengetahui apakah earnings management berpengaruh langsung terhadap corporate environmental responsibility disclosure. Dari tabel 5 diketahui bahwa nilai signifikasi 0,242 dengan koefisien -0,680. Dari hasil tersebut dapat diketahui bahwa earnings management tidak berpengaruh secara signifikan terhadap tanggung jawab sosial dan lingkungan perusahaan. Dengan demikian dapat disimpulkan bahwa $\mathrm{H1} \underline{\text { di- }}$ tolak karena tidak sejalan dengan hipotesis pertama yang menyatakan bahwa earnings management berpengaruh secara signifikan terhadap CERD.

Hasil penelitian ini sejalan dengan beberapa penelitian sebelumnya yang menemukan bahwa tidak ada pengaruh yang signifikan antara earnings management dengan corporate social responsibility diaclosure (Chih et al. 2008; Sun et al. 2010; Djuitaningsih dan Marsyah 
2012; dan Terzaghi 2012). Chih et al (2008) menemukan bahwa perusahaan besar dengan kualitas audit yang baik lebih memilih membuat pengungkapan dibanding manipulasi laba. Selain itu mereka memprediksi bahwa perusahaan yang melakukan CSR tidak hanya berkonsentrasi pada peningkatan penghasilan, tetapi juga manajemen stakeholders.

\section{Hipotesis Kedua}

Hipotesis kedua dalam penelitian ini bertujuan untuk mengetahui pengaruh komisaris independen dalam memoderasi pengaruh earnings management terhadap CERD adalah 0,141, berarti lebih besar dari 0,05 atau 0,141<0,05. Sehingga dapat disimpulkan bahwa proporsi komisaris independen tidak berpengaruh signifikan terhadap pengaruh earnings management terhadap CERD. Berarti H2 ditolak karena tidak sejalan dengan hipotesis pertama dalam penelitian ini yang menyatakan bahwa proporsi komisaris independen berpengaruh signifikan terhadap pengaruh earnings management terhadap CERD.

Hasil pengujian hipotesis pertama ini mendukung hasil penelitian yang dilakukan Sun et al. (2010) yang menyatakan bahwa komisaris independen tidak berpengaruh signifikan terhadap perngaruh earnings management terhadap pengungkapan CER. Hal ini berarti, banyak atau sedikitnya jumlah anggota komisaris independen tidak begitu berpengaruh untuk mengendalikan earnings management. Hal ini juga dapat menjelaskan bahwa besar kecilnya proporsi komisaris independen bukan menjadi faktor utama dalam efektifitas pengawasan terhadap manajemen perusahaan. Efektifitas mekanisme pengendalian manajemen perusahaan tergantung pada nilai, norma, dan kepercayaan yang diterima dalam suatu organisasi.

\section{Hipotesis Ketiga}

Hipotesis kedua dalam penelitian ini bertujuan untuk mengetahui apakah jumlah anggota komite audit dapat memoderasi pengaruh earnings management terhadap CERD. Dari tabel 4.15 di atas diketahui bahwa nilai interaksi antara jumlah anggota komite audit dengan earnings management terhadap CERD menunjukkan nilai signifikasi 0.479, berarti lebih besar dari 0,05. Sehingga dapat disimpulkan bahwa earnings management dan jumlah anggota komite audit tidak berpengaruh secara signifikan terhadap CERD. Hasil penelitian ini tidak sejalan dengan hipotesis kedua, maka hipotesis kedua yang menyatakan bahwa H3 ditolak.

Dari hasil pengujian hipotesis kedua ini juga mendukung hasil penelitian yang dilakukan oleh Sun et al (2010) yang menyatakan bahwa jumlah anggota komite audit tidak berpengaruh signifikan terhadap pengaruh earnings management terhadap pengungkapan CER. Banyak atau sedikitnya jumlah anggota komite audit tidak terlalu mempengaruhi manajemen perusahaan untuk melakukan CERD demi menutupi kecurangan earnings management.

\section{Hipotesis Keempat}

Hipotesis keempat bertujuan untuk mengetahui apakah institusional ownership dapat memoderasi pengaruh earnings management terhadap CERD. Dari tabel 4.15 di atas nilai variabel interaksi antara earnings management dan institusional ownership terhadap CERD adalah 0,007 yang berarti tidak lebih besar dari 0,05 atau $0,007<0,05$ yang artinya earnings management dan institusional ownership berpengaruh signifikan terhadap CERD. Hasil penelitian ini sejalan dengan hipotesis, maka hipotesis keempat yang menyatakan bahwa earnings management dan institusional ownership berpengaruh signifikan terhadap CERD, maka H4 diterima.

Hasil pengujian hipotesis ketiga bertentangan dengan penelitian yang dilakukan Djuitaningsih dan Marsyah (2012) yang menyatakan bahwa institusional ownership tidak berpengaruh terhadap pengungkapan CERD. Akan tetapi, pada kenyataannya proporsi kepemilikan saham oleh institusi di Indonesia memiliki pro- 
porsi yang besar, sehingga akan menuntut manajemen agar melakukan pengungkapan CER kepada para stakeholders secara sukarela tanpa adanya niat untuk menutupi kecurangan earnings management yang mungkin dilakukan.

\section{Hipotesis Kelima}

Hipotesis kelima bertujuan untuk mengetahui apakah managerial ownership dapat memoderasi pengaruh earnings management terhadap CERD. Hasil dari Uji t pada tabel 4.15 di atas menunjukkan bahwa nilai signifikasi dari variabel interaksi antara earnings management dan managerial ownership terhadap CERD adalah 0,751. Berarti lebih besar dari 0,05. Hal ini berarti earnings management dan managerial ownership tidak berpengaruh signifikan terhadap CERD. Hal ini tidak sejalan dengan hipotesis keempat yang menyatakan bahwa earnings management dan managerial ownership berpengaruh signifikan terhadap CERD, maka H5 ditolak.

Hasil dari pengujian hipotesis kelima tersebut sejalan dengan penelitian yang dilakukan Djuitaningsih dan Marsyah (2012), Said et al.(2009) dan Waryanto (2010) yang menyatakan bahwa kepemilikan saham oleh pihak manajemen tidak mempengaruhi pengungkapan CSR perusahaan. Hal ini sangat mungkin terjadi, karena rata-rata manajerial ownership perusahaan manufaktur di Indonesia relatif kecil, sehingga masih terjadi kemungkinan adanya benturan kepentingan antara manajemen perusahaan dengan para stakeholders, dimana pihak manajemen tidak berusaha secara maksimal untuk meningkatkan nilai perusahaan yang sejalan dengan kepentingan pemilik perusahaan.

\section{Firm's Size (Ukuran Perusahaan)}

Ukuran Perusahaan dalam penelitian ini diproksikan dengan total asset. Hasil penelitian menunjukkan nilai signifikasi 0,000 dengan koefisien sebesar 0,061. Dari hasil tersebut dapat disimpulkan bahwa Ukuran perusahaan berpengaruh signifikan terhadap pengungkapan CER. Hal ini berarti ukuran perusahaan akan meningkatkan CERD yang dilakukan perusahaan.

Hasil penelitian ini menunjukkan bahwa semakin besar ukuran perusahaan, maka CERD yang dilakukan akan semakin kompleks. Hasil penelitian ini mendukung penelitian sebelumya yang dilakukan oleh Belkaoui dan Kapik (1989); Setyorini dan Zuaini (2012), dan Sembiring (2005). Menurut Sembiring (2005) perusahaan besar akan lebih banyak untuk disoroti, pengungkapan merupakan salah satu cara untuk mengurangi biaya politis sebagai wujud tanggung jawab sosial dan lingkungan perusahaan terhadap para stakeholders.

\section{Leverage}

Leverage dalam penelitian ini diukur dengan menggunakan persentase perbandingan antara total utang dan total asset. Hasil penelitian menunjukkan nilai signifikasi leverage sebesar 0,315 dengan koefisien sebesar $-0,14$ yang artinya leverage tidak berpengaruh signifikan terhadap pengaruh earnings management terhadap CERD. Hal ini berarti tingkat leverage perusahaan tidak berpengaruh signifikan terhadap pengaruh earnings management terhadap CERD yang dilakukan perusahaan.

Hasil penelitian ini bertentangan dengan hasil penelitian yang diungkapkan oleh Lawer (2010), dan Susilatri et al. (2011) yang menyatakan bahwa tingkat leverage perusahaan berpengaruh signifikan terhadap pengungkapan CER yang dilakukan perusahaan.Pada dasarnya, leverage merupakan tingkat kemampuan perusahaan untuk memenuhi kewajibannya, sehingga tidak ada alasan bagi manajemen untuk memanipulasi laba atau melakukan earnings management dan melakukan pengungkapan CER untuk menutupi kecurangan yang mungkin terjadi.

\section{Profitabilitas}

Profitabilitas dalam penelitian ini diproksikan dengan Return on Assets (ROA) dari tabel 4.15 di atas menunjukkan nilai 0,134 dengan koefisien 0,013, yang artinya Profitabilitas tidak berpengaruh signifikan 
terhadap pengaruh earnings management terhadap pengungkapan CER.

Hasil penelitian ini mendukung hasil penelitian yang dilakukan oleh Rosmanita (2007) dan Sembiring (2003 dan 2005), keduanya menyatakan bahwa tidak ada pengaruh yang signifikan antara profitabilitas terhadap CSR. Vance (1975) menyatakan bahwa pengungkapan sosial perusahaan justru akan memberikan kerugian yang kompetitif (Competitive disadvantage) karena perusahaan harus mengeluarkan tambahan biaya untuk mengungkapkan informasi sosial tersebut. Hal ini berarti tidak ada alasan bagi pihak manajemen untuk melakukan pengungkapan CER hanya untuk menutupi kecurangan earnings management yang mungkin dilakukannya.

\section{SIMPULAN}

Dari analisis data yang dilakukan diatas, maka dapat disimpulkan bahwa:

Earnings management tidak berpengaruh signifikan terhadap corporate environmental responsibility disclosure. Proporsi komisaris independen tidak berpengaruh signifikan dalam memoderasi pengaruh earnings management terhadap pengungkapan corporate environmental responsibility disclosure. Institusional ownership atau proporsi kepemilikan institusi berpengaruh signifikan dalam memoderasi pengaruh earnings management terhadap corporate environmental responsibility disclosure.

Managerial ownership atau proporsi kepemilikan manajerial tidak berpengaruh signifikan dalam memoderasi pengaruh earnings management terhadap corporate environmental responsibility disclosure.

Profitabilitas tidak berpengaruh signifikan terhadap pengaruh earnings management terhadap corporate environmental responsibility disclosure. Leverage tidak berpengaruh signifikan terhadap pengaruh earnings management terhadap corporate environmental responsibility disclosure. Firms size atau ukuran perusahaan berpengaruh signifikan terhadap pengaruh earnings management terhadap corporate environmental responsibility disclosure. Hal ini mungkin terjadi, karena semakin besar ukuran perusahaan akan semakin mendorong manajemen untuk melakukan pengungkapan corporate environmental responsibility, untuk mendapatkan perhatian dari para stakeholder.

\section{DAFTAR PUSTAKA}

Akhtaruddin, M. et al. 2009. Corporate governance and voluntary disclosure in corporate annual reports of Malaysian listed firms. Journal of Applied Management Accounting Research, 7 (1): 1-20.

Anggraini, Fr. R. R. 2006. Pengungkapan Informasi Sosial dan Faktor-Faktor yang Mempengaruhi Pengungkapan Informasi sosial dalam Laporan Keuangan Tahunan (Studi Empiris pada Perusahaan-Perusahaan yang Terdaftar di Bursa Efek Jakarta). Simposium Nasional Akuntansi IX, Padang, Indonesia.

Abed,S., A. Al-Attar dan M. Suwaidan. 2012. Corporate governance and earnings management: Jordanian evidence. International Business Research, 5 (1): 216-225.

Badjuri, A. 2011. Faktor-faktor Fundamental, MekanismeCorporate Governance,PengungkapanCorporat e Social responsibility Perusahaan Manufaktur dan Sumber Daya Alam di Indonesia (Corporate Governance Mechanism, Fundamental Factors, Corporate Social Responsibility Disclosure of Natural Resource and Manufactur Company In Indonesia).Dinamika Keuangan dan Perbankan, 3(1):38-54.

Bangun, N. dan Vincent. 2008. Analisis Hubungan Komponen Good Corporate Governance terhadap Manajemen Laba dengan Kinerja Keuangan pada Perusahaan Manufaktur yang Terdaftar di Bursa Efek Indonesia. Jurnal Akuntansi, 12(03): 289-302.

Belkaoui, A. dan Karpik, P. G. 1989. Determinants of the Corporate Decisions to Disclose Social Information. Accounting, Auditing, and Accountability Journal, 2 (1): 36 -51 .

Boediono, G. SB. 2005. Kualitas Laba : Studi Pengaruh Mekanisme Corporate Governance dan Dampak Manajemen Laba dengan Menggunakan Analisis Jalur. 
Simposium Nasional Akuntansi VIII. Solo.

Benardi, M.K, Sutrisno dan P. Assih. 2009. Faktor-faktor Yang Memengaruhi Luas Pengungkapan dan Implikasinya terhadap Asimetri Informasi. Simposium Nasional Akuntansi XII, Palembang, Indonesia.

Boediono. 2005. Pengaruh Mekanisme Corporate Governance terhadap Manajemen Laba dan Dampaknya pada Kualitas Laba. Jurnal Akuntansi, 9(3): .232-244.

Bursa Efek Indonesia. 2008. IDX Fact Book 2008. Diakses pada 13 Juli 2013 dari http://www.idx.co.id . 2009. IDX Fact Book 2009 Diakses pada 13 Juli 2013 dari http://www.idx.co.id.

- - - - - - ---. 2010. IDX Fact Book 2010 Diakses pada 13 Juli 2013 dari http://www.idx.co.id. 2011 Diakses pada 13 Juli 2013 dari http://www.idx.co.id.

Chih, H., C. Shen dan F. Kang. 2008. Corporate Social Responsibility, Investor Protection, and Earnings Management: Some International Evidence, Journal of Business Ethics, 79(1/2): 179-198.

Christiana, L. 2012. Faktor-Faktor yang Mempengaruhi Praktek Perataan Laba pada Perusahaan Manufaktur di BEI. Jurnal Ilmiah Mahasiswa Akuntansi. 1(4): 71-75.

Dahlan, A. 2003. Disclosure dan Corporate Governance: Suatu tinjauan teoritis. Telaah Ekonomi, Manajemen, dan Akuntansi, 4(1): 48-62.

Djuitaningsih, T. dan W. A. Marsyah. 2012. Pengaruh Manajemen Laba dan Mekanisme Corporate Governance Terhadap Corporate Social Responsibility Disclosure. Media Riset Akuntansi, 2(2): 187-211.

Eckel, N. 1981.The Income Smoothing Hypothesis Revisited. ABACUS, 17 (1): 28-40.

Effendi, B., L. Uzliawati dan A. S. Yulianto. 2012. Pengaruh Dewan Komisaris terhadap Environmental Disclosure Pada Perusahaan Manufaktur yang Listing di Bursa Efek Indonesia Tahun 2008-2011. Simposium Nasional Akuntansi XV, Banjarmasin, Indonesia.

Fatayatiningrum, D. 2011. Analisis Pengaruh Earnings Management dan Mekanisme Corporate
Governance terhadap Corporate Environmental Disclosure (Studi Empiris pada Perusahaan yang Terdaftar di BEI Tahun 2008-2009). Skripsi, Universitas Diponegoro, Semarang.

Ghozali, I. 2006. Aplikasi Analisis Multivariate dengan Program SPSS. Semarang : Badan Penerbit Universitas Diponegoro.

Ghozali, I. dan A. Chairi. 2003. Teori Akuntansi(Edisi Revisi). Semarang: Badan Penerbit Universitas Diponegoro. 2007. Teori Akuntansi. Badan Penerbit Universitas Diponegoro: Semarang.

Global Reporting Initiative. 2006. Pedoman Laporan Berkelanjutan. GRI: Boston. Diakses: 5 Mei 2013 Jam: 21:22 Wib, dari www.global-reporting.org.

Gujarati, D. N. dan D. C. Porter. 2010. Dasar -dasar Ekonometrika (Terjemahan). Buku 1, Edisi Kelima. Jakarta : Salemba Empat.

Hadi, N. 2011. Corporate Social Responsibility. Yogyakarta :Graha Ilmu.

Handajani, L., Sutrisno dan G. Chandrarin. 2008. The Effect of Earnings Management and Corporate Governance Mechanism to Corporate Social Responsibility Discosure: Study at Public Companies in Indonesia Stock Exchange. Simposium Nasional Akuntansi XII, Palembang, Indonesia.

Haniffa, R.M. dan T.E. Cooke. 2005. The Impact of culture and governance on corporate social reporting. Journal of Accounting and Public Policy, 24(5): 391-430.

Hardhina, R. 2007. Faktor-faktor yang mempengaruhi Pengungkapan Sosial (Social Disclosure) dalam Laporan Keuangan Tahunan Perusahaan Manufaktur di Bursa Efek Jakarta. Skripsi Tidak Dipublikasikan, Universitas Islam Indonesia, Yogyakarta.

Healy, P.M. dan J.M. Wahlen. 1999. A Review of the Earnings Management Literature and Its Implications for Standard Setting. Accounting Horizons, 13(4): 365 - 383.

Herawaty, V. 2008. Peran Praktek Corporate Governance Sebagai Moderating Variable dari Pengaruh 
Earnings Management terhadap Nilai Perusahaan. Simposium Nasional Akuntansi XI, Pontianak, Indonesia.

Jensen, M.C. dan W. H. Meckling. 1976. Theory of the Firm: Managerial Behavior, Agency Cost and Ownership Structure. Journal of Financial Economics, 3(4): 305-360.

Joyce Kumaat, John Haluan, Sugeng Hari Wisudo, Daniel R Monintja. Jurnal Marine Fisheries Jurnal Marine Fisheries 41-50 jilid 4 terbitan 1

KNKG (Komite Nasional Kebijakan Governance) .2006. Pedoman Umum Good Corporate Governance Indonesia. Jakarta.

Lako, A. 2008. Laporan Keuangan dan Konflik Kepentingan. Edisi Kedua. Yogyakarta: Amara Book.

Lawer, C. 2010. Pengaruh Karakteristik Perusahaan Terhadap Pengungkapan Tanggung Jawab Sosial Perusahaan pada Perusahaan Properti dan Real Estate Tahun 2007. Skripsi Tidak Dipublikasikan, Universitas Riau Pekanbaru.

Mestuti, A. S. dan S. Muthmainah. Analisis Pengaruh Manajemen Laba Terhadap Tanggung Jawab Sosial dan Lingkungan Dengan Corporate Governance Sebagai Variabel Moderating (Studi Kasus pada Perusahaan Manufaktur yang Terdaftar Di BEI Tahun 20092010).Jurnal Akuntansi dan Bisnis, 6 (2): 163-172.

Midiastuty, P. P. dan M. Machfoedz. 2003. Analisis Hubungan Mekanisme Corporate Governance dan Indikasi Manajemen Laba. Simposium Nasional V, Surabaya, Indonesia.

Munawir, S. 1986. Analisis Laporan Keuangan. Yogyakarta : Liberty.

Post, J. E., A. T. Lawrence dan J. Weber. 2002. Business and Society: Corporate Strategy, Public Policy and Ethics. 10ed. New York: Mc. GrawHill.

Prior, D., J. Surroca dan J. A. Tribo. 2008. Are Socially Responsible Managers Really Ethical? Exploring the Relationship Between Earnings Manajegemnt and Corporate Social Responsibility. Journal Compilation, 16(3): 160-177.

Rahmawati dan Dianita, P. S. 2011. Analysis of the Effect of Corporate Social Responsibility on Financial
Performance with Earnings

Management as a Moderating

Variable. Journal of Modern Accounting and Auditing, 7(10): 1034-1045.

Rawi. 2008. Pengaruh kepemilikan manajemen, Institusional dan Leverage terhadap Corporate Social Responsibility pada Perusahaan Manufaktur yang Listing di Bursa Efek Indonesia. Tesis (Tidak Dipublikasikan), Universitas Diponegoro, Semarang.

Said, R., Y. Zainuddin dan H. Haron. The relationship between corporate social responsibility disclosure and corporate governance characteristics in Malaysian public listed companies. Social Responsibility Journal, 5(2): 212 - 226.

Ross, S.A., R.W. Westerfield dan B. D. Jordan. 2008. Corporate Finance Fundamental. New York: McGraw Hill Irwin.

Sanusi, A. 2011. Metodologi Penelitian Bisnis. Jakarta: Salemba Empa.

Sari, R. N., R. Anugerah, dan R. Dwiningsih. 2010. Pengaruh Struktur Kepemilikan, Kualitas Audit dan Ukuran Perusahaan Terhadap Transparasi Informasi (Studi Empiris pada 100 Perusahaan Publik Terbesar Di Indonesia). Jurnal Pendidikan dan Bisnis (Pekbis), 2(3): 326-335.

Scott, W.R. 2000. Financial Accounting Theory. 2ed. Ontario: Prentice-Hall Canada Inc.:Scarborough.

Sekaran, U. dan R. Bougie. 2009. Research Methods For Business : A SkillBuilding Approach. 5ed. United Kingdom : Wiley.

Shah, S.Z.A., S.A. Butt dan A. Hasan. 2009. Corporate Governance and Earnings Management an Empirical Evidence Form Pakistani Listed Companies. European Journal of Scientific Research, 26( 4): 624-638.

Sembiring, E. R. 2003. Kinerja Keuangan, Political Visibility, Ketergantungan pada Hutang dan Pengungkapan Tanggung Jawab Sosial Perusahaan. Simposium Nasional Akuntansi VI. Surabaya, Indonesia.

2005. Karakteristik perusahaan dan Pengungkapan Tanggung Jawab Sosial: Studi Empiris pada Perusahaan yang tercatat di Bursa Efek Jakarta. Simposium Nasional 
VIII, Solo, Indonesia.

Setyarini, Y. dan M. Paramitha. 2011. Pengaruh Mekanisme Good Corporate Governance terhadap Corporate Social Responsibility. Jurnal Kewirausahaan, 5(2): 10-17.

Setyorini, T. C. dan Zuaini, I. 2012. Corporate social and Environmental Disclosure: A Positive Accounting Theory View Point. International Journal of Business and Social Science, 3(9) : 152-164.

Solihin, I. 2009. Corporate Social Responsibility: From Charity to Sustainbility. Jakarta :Salemba Empat.

Suhardjanto, D. dan U. Choiriyah. 2010. Information GAP: Demand Supply Environmental Disclosure di Indonesia. Jurnal Keuangan dan Perbankan,14(1): 36-51.

Suhardjanto, D. dan D. N. Permatasari. 2010. Pengaruh Corporate Governance, Etnis, dan Latar Belakang Pendidikan Terhadap Environmental Disclosure (Studi Empiris pada Perusahaan Listing di Bursa Efek Indonesia). Jurnal Bisnis dan Ekonomi,14(2): 151-164.

Sulistiyanto, H. S. 2008. Manajemen Laba (Teori dan Model Empiris). Jakarta: Grasindo.

Sun, N. et al. 2010. Corporate Environmental Disclosure, Corporate Governance, and Earnings Management. Managerial Auditing Journal, 25(7): 629-700.

Susanti, S. I. A. 2011. Pengaruh Kualitas Corporate Governance, Kualitas Audit, dan Earnings Management terhadap Kinerja Perusahaan. Jurnal Ekonomi dan Bisnis, 5(2): 145-16.

Susilatri, R. Agusti dan D. Indriani. 2011. Pengaruh Leverage, Profitabilitas, Size, Umur Perusahaan dan Ukuran Dewan Komisaris Terhadap Pengungkapan Tanggungjawab Sosial Perusahaan (Studi pada Perusahaan Pertambangan yang Listing Di BEI Tahun 2004-2008). Jurnal Pendidikan dan Bisnis (Pekbis), 3(1): 421-428.

Sri Sulistyanto. 2008. Manajemen Laba Teori Dan Model Empiris. Jakarta:Grasindo
Tehranian, H. et al. 2006. Earnings Management, Corporate Governance, and True Financial Performance Working Paper, Available at SSRN:http://ssrn.com/.

Terzaghi, M. T. 2012. Pengaruh Earnings Management dan Mekanisme Corporate Governance terhadap Pengungkapan Tanggung Jawab Sosial Perusahaan Manufaktur yang Terdaftar di Bursa Efek Indonesia. urnal Ekonomi dan Informasi Akuntansi, 2(1):. 31-47.

Republik Indonesia. Undang-Undang No 40. 2007 Tentang Perserosan Terbatas.

Ubgede, O., M. Lizam dan A. Kaseri. 2013. Corporate governance and earning management: empirical evidence from malaysian and nigerian banks. Asian Journal of Management Sciences \& Education, 2(4): 11-21.

Untung, H. B. 2008. Corporate Social Responsibility. Yogyakarta: Badan Penerbit Sinar Grafika:

Vance, S.C. 1975. Are Socially Responsible Corporations Good Investment Risks?. Management Review, 64(8): 19-24.

Veronica, S. dan Y. S. Bachtiar. 2005. Good Corporate Governance Information Asymetry and Earnings Management. Jurnal Akuntansi dan Keuangan Indonesia. 2. (1). 77-106.

Waryanto. 2010. Pengaruh Karakteristik Good Corporate Governance (GCG) Terhadap Pengungkapan Corporate Social Responsibility di Indonesia. Skripsi (Tidak Dipublikasikan), UniversitasDiponegoro, Semarang.

Yip, E., S. Cana dan C. V. Staden. 2011. Corporate Social Responsibility and Earnings Management: The Role of Political Cost. Australasian Accounting Business and Finance Journal, 5( 3): 17-3.

Zahra, S.A., R. L. Priem dan A. A. Rasheed. 2005. The Antecedents and Consequences of Top Management Fraud. Journal of Management, 31 (6): 803-828. 
